\title{
Investigating Awareness of Emergency Evacuation Among Construction Workers
}

\author{
Norafneeza Norazahar ${ }^{1,2^{*}}$, Hamidi Murad ${ }^{2}$ \\ ${ }^{1}$ Centre of Hydrogen Energy, Institute of Future Energy, Universiti Teknologi Malaysia, 81310 Johor Bahru, \\ Malaysia \\ ${ }^{2}$ School of Chemical and Energy Engineering, Faculty of Engineering, Universiti Teknologi Malaysia, 81310 \\ Johor Bahru, Malaysia \\ *Corresponding author: norafneeza@utm.my
}

Article History

Received: May 10, 2019 Received in revised form: August 08, $2019 \quad$ Accepted: October 31, $2019 \quad$ Published Online: December 09, 2019

\begin{abstract}
Emergency evacuation at construction site is challenging to be conducted due to its dynamic conditions and changing layout. This paper presents a survey work on awareness of emergency evacuation among construction workers. One construction site, P32-2 in Forest City, Johor Bahru is selected for the survey work. 300 workers participated in the survey work. The survey consists of seven questions related to demographic, education levels, and emergency evacuation training. Based on the feedbacks, many workers are male and are in the age group between 20 to 30 years old. The construction site has more general workers than others position. The principal employers or contractors prefer to hire individuals who have no proper education as general workers. There are three challenges for instilling safety awareness of emergency evacuation effectively, which are i) a large number of workers, ii) low level of education, and iii) no training and experience in the emergency evacuation at construction site. This paper did not study worker's competency to perform the emergency evacuation. More research work on emergency evacuation at construction site should be conducted to improve safety of construction workers.
\end{abstract}

Keywords: Construction; emergency response plan; evacuation; hazards; safety.

\subsection{INTRODUCTION}

\subsection{The Emergency Response Plans for Construction Sites}

The value of Malaysia's construction work in 2018 is estimated RM 145.5 billion, which 5.1 percent higher than the value in 2017. According to the Department of Statistics Malaysia, the expansion value of construction work was driven by positive growths in the civil engineering fields, special trades activities and non-residential buildings sub-sectors, which increased by 14.3 percent, 8.2 percent and 2.5 percent, respectively [1]. The civil engineering construction involves activities designing, constructing and maintaining the physical structure such as airports, bridges, dams, roads, and high-rise buildings. The special trade activities include the electrical, plumbing, roofing, heating, air conditioning, landscaping, and excavation services.

The construction sites are often known as the most hazardous workplace. Common hazards at the construction sites are working at height, working with rotating or heavy machines, falling objects, vehicles or traffic routes, fires and explosions, flooding, structural collapse, electric shock and burns, and noise [2]. Such hazards have high level of risks which can lead to fatalities. Examples of fatalities happened at the construction sites are falling through fragile roofs and rooflights, falling from ladders, scaffolds or other workplaces, being struck by excavators or forklift trucks, overturning vehicles, being crushed by collapsing structures [2], [3], [4]. Such situations require all workers to evacuate the area and gather at the designated assembly point [5].

Due to the presence of hazards at the construction sites, the principal employers should provide an emergency response plan for possibilities of accidents to employees or contractors. The emergency response plans can prevent further loss or injury to employees or contractors. The emergency response plans should consist of the procedures, communication systems, first aid 
facilities, fire extinguishers, spills containment equipment, training, and evacuation exercises [6]. Therefore, both the principal employers and employees must be aware of the availability of emergency response plans provided at the construction site.

The Department of Occupational Safety and Health (DOSH) Malaysia prepared a few questions pertaining to the emergency response plans at the construction site. DOSH suggested the principal employers to consider these questions when preparing or developing the emergency response plans for the construction work. The questions are listed in Table 1 [7].

Table 1. Questions to be considered when developing the emergency response plans.

\begin{tabular}{|c|l|}
\hline No. & Questions pertaining to emergency response plans [7] \\
\hline 1 & How will the principal employers provide the necessary information and protection for workers? \\
\hline 2 & $\begin{array}{l}\text { What is first aid and medical equipment required on site? } \\
* \text { The principal employers must take account number of workers, distance to medical services and inherent hazards. }\end{array}$ \\
\hline 3 & $\begin{array}{l}\text { How will the emergency response team reach an injured worker and get them to medical help? } \\
* \text { The injured worker could be suspended in a harness or trapped in a confined space. }\end{array}$ \\
\hline 4 & How should the emergency response team account for all workers in the event of an emergency evacuation? \\
\hline 5 & In case of a fire or chemical spill, how will the principal employers and emergency response team contain it? \\
\hline 6 & How will the principal employers secure the construction site in an emergency to prevent further loss? \\
\hline 7 & How should the emergency response team disconnect or isolate all energy sources, e.g. gas or steam? \\
\hline
\end{tabular}

Construction work has dynamic situations and environment which causing the principal employers to update the emergency response plans regularly. The layout of the building under construction work and its interconnectivity will change from time to time following the schedule. The changes should be shared with all workers at the construction site. The fire safety engineering group of University of Greenwich stated that more research work should focus on the emergency response plans for the changing layout and conditions at construction sites [8]. The research work should also study the effectiveness of emergency evacuation at construction sites.

Workers at constructions sites usually come from other countries, which have different backgrounds, language and level of education [9]. Risk perception among workers could also be differ from each other. Due to these factors, worker's awareness on the changing emergency response plan and evacuation is questionable. Moreover, their skills of performing evacuation during emergencies is also uncertain.

This paper presents a survey on workers' awareness on emergency response plans and evacuation at construction sites. The objective of survey is to investigate the level of awareness of workers about evacuation and emergency at construction sites. The survey was conducted on one specific location of construction work, which is P32-2 in Forest City, Johor Bahru. The layout of construction work is shown in Figure 1. The construction work is to build a build-rise of minimal 5 stories height. The escape routes being considered in the survey are staircase, corridor, hearth door, and intermediate ground.

This paper describes the preparation of survey in Section 2. Results and discussion are presented in Section 3. Finally, this paper concludes the survey in Section 4.

\subsection{METHODOLOGY}

This paper discusses the preparation and distribution of questionnaire to workers at construction site in Sections 2.1 and 2.2, respectively. Section 2.3 explains the analysis of feedbacks to the questionnaire.

\subsection{Prepare the Questionnaire}

The questionnaire is prepared and listed in Table 2. Questions 1 to 4 are related to the worker's background specifically gender, age groups, job position, and level of education. Questions 5 to 7 ask workers on their participation in emergency evacuation training and fire drills.

\subsection{Distribute the Questionnaire}

The questionnaire is distributed to workers at construction site known as P32-2. 1400 workers including the management team are stationed at the construction site. The questionnaire is distributed during a safety briefing, which usually conducted in the morning. 


\subsection{Analyse the Feedback}

The feedback is analysed using the Microsoft Excel (MS Excel), which can simplify the calculation according to questions. The graph is also generated using the MS Excel.

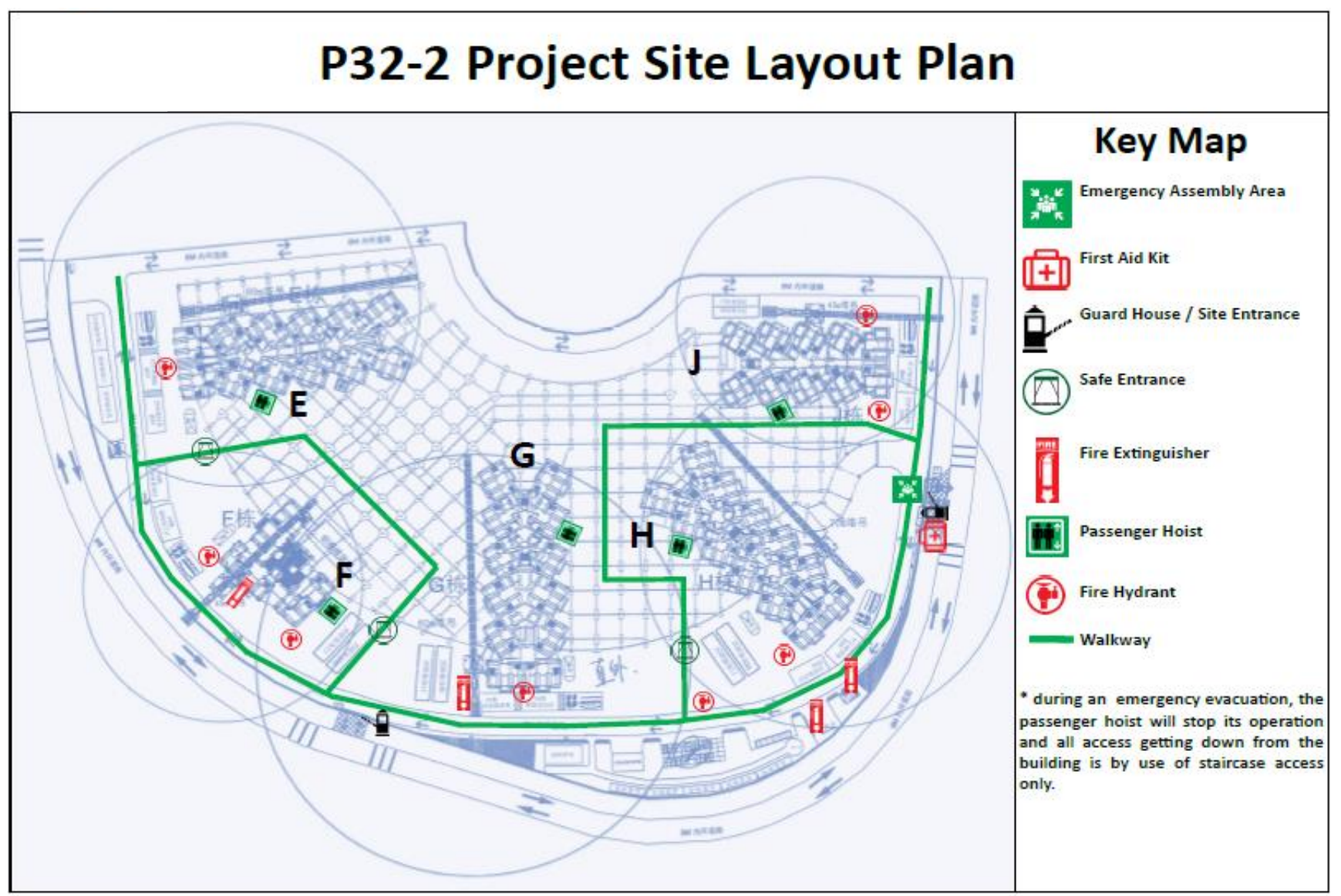

Figure 1. The layout of construction work P32-2 in Forest City, Johor Bahru.

Table 2. Questions of worker's backgrounds and experience.

\begin{tabular}{|c|c|c|}
\hline No. & Questions & Options for feedback \\
\hline 1 & Indicate gender & $\begin{array}{ll}\circ & \text { Female } \\
\circ & \text { Male }\end{array}$ \\
\hline 2 & Education level & $\begin{array}{ll} & \text { Bachelor } \\
\circ & \text { Diploma } \\
\circ & \text { Secondary school } \\
\circ & \text { Primary school } \\
\circ & \text { None }\end{array}$ \\
\hline 3 & Indicate age group & $\begin{array}{ll} & 20-30 \text { years old } \\
\circ & 31-40 \text { years old } \\
\circ & 41-50 \text { years old } \\
\circ & 51-60 \text { years old } \\
\circ & 61+\text { years old }\end{array}$ \\
\hline 4 & Job position & $\begin{array}{ll} & \text { Consultant } \\
\circ & \text { Manager } \\
\circ & \text { Officer } \\
\circ & \text { Engineer } \\
\circ & \text { Supervisor } \\
\circ & \text { General worker }\end{array}$ \\
\hline 5 & Have you received or attend formal course on emergency evacuation? & $\begin{array}{ll}\circ & \text { Yes } \\
\circ & \text { No }\end{array}$ \\
\hline 6 & Do you have any experiences of being involved in emergency evacuation at construction site? & $\begin{array}{ll}\circ & \text { Yes } \\
\circ & \text { No }\end{array}$ \\
\hline 7 & Have you participated in fire drills at construction site? & $\begin{array}{ll}\circ & \text { Yes } \\
\circ & \text { No }\end{array}$ \\
\hline
\end{tabular}




\subsection{RESULTS AND DISCUSSION}

300 out of 1400 workers at the construction site has participated in the survey and answered all questions. The results are presented in Section 3.1. Section 3.2 discusses the findings from the survey.

\subsection{Analysis of Feedback}

i) Question 1

Table 3 shows that the workers are mostly male. Female workers are also working at the construction site. The result of survey indicate that the ratio of female workers to male is $1: 14$.

Table 3. The proportion of gender.

\begin{tabular}{lccc}
\hline Characteristics & & Number $(\mathbf{n}=\mathbf{3 0 0})$ & Percentage (\%) \\
\hline \multirow{2}{*}{ Gender } & Male & 280 & 93.3 \\
& Female & 20 & 6.7 \\
\hline
\end{tabular}

\section{ii) Question 2}

The highest education level in the questionnaire is bachelor degree, followed by diploma, secondary and primary school. The question provides an option of no education. Based on the feedback, 79 percent of workers at the construction have no education or not attending school as shown in Table 4.

Table 4. The proportion of educational level.

\begin{tabular}{llcc}
\hline Characteristics & & Number $(\mathbf{n}=\mathbf{3 0 0})$ & Percentage (\%) \\
\hline & Bachelor & 26 & 8.7 \\
Educational Level & Diploma & 14 & 4.7 \\
& Secondary & 0 & 0 \\
& Primary & 22 & 7.3 \\
& None & 238 & 79.3 \\
\hline
\end{tabular}

\section{iii) Question 3}

There are 5 age groups in the questionnaire as shown in Table 5. Many workers are in the age group between 20 to 30 years old. The second highest age group is between 31 to 40 years old. From the survey, there is no workers aged more than 61 years old.

Table 5. The proportion of age group.

\begin{tabular}{llcc}
\hline Characteristics & & Number $(\mathbf{n}=\mathbf{3 0 0})$ & Percentage (\%) \\
\hline & 20-30 Years Old & 114 & 38.0 \\
3ge & 31-40 Years Old & 74 & 24.7 \\
& 41-50 Years Old & 63 & 21.0 \\
& $51-60$ Years Old & 49 & 16.3 \\
& 61+ years old & 0 & 0 \\
\hline
\end{tabular}

\section{iv) Question 4}

Consultant is the highest job position considered in the survey. It is followed by the site manager, engineer, officer, supervisor, and general worker. General workers are an unskilled worker, which can be assigned to tasks that does not require special skills. Table 6 lists the distribution of job positions at the construction wite of P32-2 in Forest City. The construction site has many general workers.

Table 6. The proportion of job positions.

\begin{tabular}{llcc}
\hline Characteristics & & Number (n=300) & Percentage (\%) \\
\hline \multirow{4}{*}{ Job Position } & Consultant & 10 & 3.3 \\
& Site manager & 8 & 2.7 \\
& Engineer & 2 & 0.7 \\
& Officer & 4 & 1.3 \\
& Supervisor & 16 & 5.3 \\
\hline
\end{tabular}


v) Question 5

Table 7 presents the number of workers attending the emergency evacuation training. 68 percent of workers received or attended the training. Another 32 percent stated they did not receive or attend the training.

Table 7. The proportion of workers attending emergency evacuation training.

\begin{tabular}{lcc}
\hline Characteristics & & Number (n=300) \\
\hline $\begin{array}{l}\text { Have you received or attended any formal course(s) on emergency } \\
\text { evacuation? }\end{array}$ & Yes & 204 \\
& No & 68.0 \\
\hline
\end{tabular}

\section{vi) Question 6}

The survey futher asked the workers whether they have experience in emergency evacuation or not. 76.7 percent of workers used to be involved in the emergency evacuation at the construction site. The percentage of worker's experience in emergency evacuations is shown in Table 8.

Table 8. The proportion of worker's experience in emergency evacuation.

\begin{tabular}{lcc}
\hline Characteristics & & Number $(\mathbf{n = 3 0 0})$ \\
\hline $\begin{array}{l}\text { Do you have any experience of being involved in emergency } \\
\text { evacuation at construction site? }\end{array}$ & Yes & 230 \\
& No & 76.7 \\
\hline
\end{tabular}

\section{vii) Question 7}

Finally, the survey includes the question related to worker's participation in fire drills. Referring to Table 9, 79.3 percent of workers stated they participated in fire drills. Another 20.7 percent of workers did not participate in the fire drills.

Table 9. The proportion of workers participating in fire drills.

\begin{tabular}{lcc}
\hline Characteristics & & Number $(\mathbf{n = 3 0 0})$ \\
\hline Have you participated in fire drills at construction site? & Yes & 238 \\
& No & 62 \\
\hline
\end{tabular}

\subsection{Discussion}

This paper discusses three challenges for instilling safety awareness of emergency evacuation at the construction site. The challenges are i) a large group of workers, ii) education levels of workers, and iii) training and experiences in emergency evacuation at the construction site.

\section{i) A Large Group Of Workers}

The study shows that one construction site could involve a large group of workers. This paper takes one construction site, which has 1400 workers. Based on Figure 1, the principal employer provides one emergency assembly area. The challenge to the principal employers is to count all workers at the assembly area in the event of emergencies. The challenge is also similar to the question raised by the Department of Occupational Safety and Health (DOSH) Malaysia [7].

A large group of workers must be coordinated properly during emergency evacuation. The coordination should consist of collaboration and synchronization. The principal employers, consultants, managers, engineers, supervisors must be responsible according to roles as assigned in the emergency response plan. They must also keep to the planned time for a safe evacuation. In return, the general workers must know their responsibility, which is to follow the instructions during the emergencies.

Communication is a priority while conducting the emergency evacuation involving a large group of workers. Proper instructions or accurate messages should be quickly delivered to workers in case of emergencies. Therefore, the communicaton system is required in the emergency response plan for construction activities. The UK HSE [3] and CSAO [6] emphasize that a reliable communication system should be provided at the construction site. Neither emergency alarm nor any communication medium identified at the construction site of P32-2 in Forest City, Johor Bahru. 


\section{ii) Workers' Education Levels}

Survey questions 1 to 4 are related to demographic and education levels. The survey shows that workers without education and general workers are two biggest groups at the construction site. The general workers are usually foreign workers. Construction work requires general workers to do many physical activities without special skills.

The emergency evacution training should be delivered according to their level of knowledge. Communication could probably become a challenge to deliver the contents of emergency evacuation training to general workers. Education level can affect communication between workers in higher level positions with general workers during the emergency evacuation. Therefore, the principal employers should use a simple language to instruct workers throughout the training and in emergencies.

\section{iii) Training and Experiences In Emergency Evacuation}

Training and worker's experiences in emergency evacuation were asked in survey questions 5 to 7 . There are some workers who did not receive training and/or never participated in the fire drills conducted at the construction site.

Effectiveness of emergency evacuation depends on the competency of workers to perform the evacuation safely. Emergency response plan should include evacuation for any possible situations such as fires, collapsed structure, and natural disaster. Fire drills is actuallty a part of emergency evacuation. In fire drills, the workers should be trained i) to access the escape route in the presence of smoke, ii) to use alternative escape route due to obstacles, or iii) to use fire extinguishers when necessary. Based on the survey, more workers participated in the fire drills than the emergency evacuation at the construction site. The survey did not include questions related to competency of workers performing fire drills. Their competency contributes to the effectiveness of evacuation due to fires.

\subsection{CONCLUSION AND RECOMMENDATION}

\subsection{Conclusion}

This paper presents the survey on construction workers' awareness on emergency evacuation. 300 workers at the construction site P32-2 in Forest City, Johor Bahru participated in the survey. Based on the results of survey, there are three challenges for instilling safety awareness of emergency evacuation effectively, which are i) a large number of workers, ii) worker's education level, and iii) worker's experiences and training. The survey shows that the awareness of emergency evacuation is not easy to be understood and implemented due to the low level of education and a large number of general workers. Safety awareness of emergency evacuation is important for everyone at the construction site because it is the last protection layer of an emergency.

\subsection{Recommendation}

More research work should focus on i) construction worker's competency performing the emergency evacuation, ii) changing layout of construction site and iii) coordination and communication for evacuating a large number of workers. The output of research work could provide data or information for emphasizing safety at construction sites.

The research work should also include the dynamic escape route and response time [10], [11]. These two variables could examine risks associated with the emergency evacuation at construction site.

\section{Acknowledgements}

Authors would like to thank to Giant Leap Company for allowing data collection at the construction site. Authors would also thank to reviewers for the inputs and comments.

\section{References}

[1] Department of Statistics Malaysia (DOSM). February 11, 2019. Retrieved from https://dosm.gov.my/v1/index.php?r=column/cthemeByCat\&cat=77\&bul_id=ejRwZys5a2Y4VFJFWHNTaUFRYjB1Zz09\&menu_id=OEY5SWtFSVV FVUpmUXEyaHppMVhEdz09. Retrieved date: April 27, 2019.

[2] Ferrett, E., \& Hughes, P. 2008. Introduction to Health and Safety in Construction. $3^{\text {rd }}$ Edition. Oxford, UK: Elsevier Ltd.

[3] Health and Safety Executive (HSE). 2006. Health and Safety in Construction. Retrieved from http://www.hse.gov.uk/pubns/priced/hsg150.pdf. Retrieved date: April 27, 2019.

[4] Department of Occupational Safety and Health Malaysia (DOSH). 2019. Fatal accident case. Retrieved from http://www.dosh.gov.my/index.php/en/component/content/article/352-osh-info/accident-case/955-accident-case. Retrieved date: May 8, 2019. 
[5] Marzouk, M., \& Daour, I.A. 2018. Planning Labor Evacuation For Construction Sites Using BIM And Agent-Based Simulation. Safety Science, 109: $174-185$.

[6] Construction Safety Association of Ontario (CSAO). 2003. Emergency response planning for construction projects. Retrieved from https://www.ihsa.ca/PDFs/Products/Id/B030.pdf. Retrieved date: May 8, 2019.

[7] Department of Occupational Safety and Health Malaysia (DOSH). 2007. Guidelines for the prevention of falls at workplace. Retrieved from http://www.dosh.gov.my/index.php/en/legislation/guidelines/building-construction-engineering-work/670-02-guidelines-for-the-prevention-of-falls-atworkplaces-2007/file. Retrieved date: April 27, 2019.

[8] Fire safety engineering group (FSEG). 2018. Improving evacuation safety of construction sites. Retrieved from https://fseg.gre.ac.uk/fire/construction_sites123.html_Retrieved date: May 6, 2019.

[9] Ingason, H., Lönnermark, A., Frantzich, H., \& Kumm, M. 2010. Fire Incidents During Construction Work Of Tunnels. Fire Technology. Science Partner Report (83).

[10] Institution of Occupational Safety and Health (IOSH). 2018. Construction site evacuation safety: Evacuation strategies for tall construction sites. Retrieved from https://www.iosh.com/media/5609/ps0876-summary-report_v2a.pdf. Retrieved date: October 29, 2019.

[11] Meouche, R. El, Abunemeh, M., Hijaze, I., Mebarki, A., \& Shahrour, I. 2018. Developing Optimal Paths for Evacuating Risky Construction Sites. Journal of Construction Engineering and Management, 144(2), 1-13. 